\title{
Fruit set and yield of apple trees cv. Gala treated with seaweed extract of Ascophyllum nodosum and thidiazuron
}

\begin{abstract}
Anelise Marques de Sousa ${ }^{1}$, Ricardo Antonio Ayub ${ }^{2}$, Thayna Viencz ${ }^{3}$, Renato Vasconcelos Botelho ${ }^{4}$
Abstract- The low effective fruiting is one of the biggest problems of apples' production in Brazil and its main cause involves the process of pollination. The objective was to evaluate the fruit set and production of apple trees cv. Gala treated with extract of seaweed Ascophyllum nodosum and thidiazuron. The experiment was carried out during two cycles (2015/2016 and 2016/2017) in Porto Amazonas, State of Paraná, Brazil, with apple trees cv. Gala. The following treatments were applied at full bloom: thidiazuron at 10 and $15 \mathrm{mg} \mathrm{L}^{-1}$, Ascophyllum nodosum seaweed extract (Algamare ${ }^{\circledR}$ ) at concentrations of $0.1,0.2,0.3,0.4$ and $0.6 \%$. No treated plants were used as control. It was evaluated: fruit set, number of fruits, fruit weight, yield per plant, number of seeds per fruit, length and diameter of fruit, length/diameter ratio (L/D), titratable acidity, soluble solids, firmness and growth of shoots. The algae extract presented similar effects of thidiazuron in apple trees, promoting, in at least one of the cycles, the increase in fruit set, number of fruits, weight and length of fruits without changing their maturation. The application of Algamare $^{\circledR}$ at $0.3 \%$ was the most effective treatment for yield improvement in 'Gala' apples.
\end{abstract}

Index terms: Malus domestica, plant regulators, algae, flowering, phytohormones.

\section{Frutificação e produtividade de macieiras cv. Gala tratadas com extrato de algas Ascophyllum nodosum e thidiazuron}

Corresponding author: rayub@uepg.br

Received: June 19, 2018 Accepted: November 09, 2018

Copyright: All the contents of this journal, except where otherwise noted, is licensed under a Creative Commons Attribution License.

\section{(cc) $\mathbf{E Y Y}$}

Resumo- A baixa frutificação efetiva é um dos maiores problemas da produção de maçãs no Brasil e tem como principal causa o processo de polinização. O objetivo foi avaliar a frutificação e produção de macieiras cv. Gala tratadas com extrato da alga marinha Ascophyllum nodosum e thidiazuron. O experimento foi conduzido durante dois ciclos (2015/2016 e 2016/2017) em Porto Amazonas, estado do Paraná, com macieiras cv. Gala. Os seguintes tratamentos foram aplicados no pleno florescimento: thidiazuron a 10 e $15 \mathrm{mg} \mathrm{L}^{-1}$, extrato de algas Ascophyllum nodosum (Algamare ${ }^{\circledR}$ ) nas concentrações de 0,$1 ; 0,2 ; 0,3 ; 0,4$ e $0,6 \%$. Plantas não tratadas foram usadas como testemunha. Foram avaliadas: frutificação, número de frutos, massa do fruto, produtividade por planta, número de sementes por fruto, comprimento e diâmetro do fruto, relação comprimento/ diâmetro, acidez titulável, sólidos solúveis, firmeza e crescimento de gemas. O extrato de alga apresentou efeitos similares ao thidiazuron em macieiras, promovendo em pelo menos um dos ciclos o aumento da frutificação efetiva, número de frutos, massa e comprimento dos frutos sem alterar a sua maturação. A aplicação de Algamare a $0,3 \%$ foi o tratamento mais efetivo no aumento da produtividade de macieiras 'Gala'.

Termos para indexação: Malus domestica, reguladores vegetais, algas, florescimento, fitohormônios.

\footnotetext{
${ }^{1}$ Agr. Eng. M.Sc. Ponta Grossa State University, Ponta Grossa-PR. Brazil. E-mail: anemsousa@gmail.com (ORCID 0000-0002-5402-9197)

${ }^{2}$ Agr. Eng. Dr. Prof. Associate. Department of Plant Engineering, Ponta Grossa State University, Ponta Grossa-PR.. Brazil. E-mail: rayub@ uepg.br (ORCID 0000-0003-3240-8417)

${ }^{3}$ Nutritionist. Master's degree in Agronomy. State University of Central-West - Unicentro. Guarapuava-PR. Brazil. E-mail: thayviencz@hotmail.com (ORCID 0000-0001-5198-9611)

${ }^{4}$ Agr. Eng Dr. Prof. Associate. Department of Agronomy, Unicentro. Guarapuava-PR. Brazil. E-mail: rbotelho@unicentro.br (ORCID 0000-00019580-2572)
} 


\section{Introduction}

The southern region of Brazil stands out for the cultivation of deciduous fruit plants, especially apple trees, which, in the last decades, has shown a remarkable development, allowing Brazil to move from importing country to exporter. According to the IBGE, in the harvest of 2015/2016, 1.14 million tons of apples were harvested, in an area of 36.3 thousand hectares. The main cultivars produced in Brazil are Gala, Fuji and their clones, which account for approximately $95 \%$ of the national apples production (ABPM, 2017).

Aiming to attend the growing demand for apple consumption, new technologies that improve the productive aspects are necessaries. The low effective fruiting is one of the biggest problems related to the production of apples in Brazil and has as main cause the limitations that involve the process of pollination. The absence of fertilization of the ovules in apple flowers results in a smaller number of fruits bearing per plant, deformed and smaller fruits and, therefore, a reduction in productivity and profitability of the orchard.

The use of plant regulators may be an alternative to maximize fruit set and improve fruit quality (FLETCHER et al., 2000; PEREIRA et al., 2014). They have a chemical structure very similar to the hormones synthesized by plants, causing low environmental impact, because they are used in very low concentrations and degrade rapidly, both in the plant and in the soil (CAMILO; DENARDI, 2006).

Among the available synthetic cytokinins with action on fruit set, thidiazuron (TDZ) is efficient in increasing the number and size of apple fruits in Brazilian conditions. Moreover, thidiazuron causes changes in the shape of the fruits that become more elongated, due to the changes in the direction of cell division (PETRI et al., 2001; PETRI; LEITE, 2008). Petri et al. (2001) also observed that the application of TDZ, when applied at full bloom, reduced the number of seeds and delayed fruit ripening.

The use of commercial products based on seaweed extracts in agriculture has grown, mainly because it is an alternative to the use of chemical fertilizers with reduced environmental impact in agricultural systems (NORRIE; HILTZ, 1999; KHAN et al., 2009; CRAIGIE, 2011). Due to the diversity of benefits provided, studies have pointed out the potential of using algae extracts to increase plant development, sometimes with consequent increases in production; as well as plant tolerance to biotic and abiotic stresses (KHAN et al., 2009; CARVALHO et al., 2013; CARVALHO et al., 2014). A considerable portion of the products derived from more than 15 million metric tons of marine algae harvested annually is used as a biostimulant in agriculture, with around 25 products being sold worldwide (FAOSTAT, 2014).
In Brazil, there are no official surveys of the number of products marketed, however, the use of algae extracts in national agriculture is already regulated by Decree No. 4,954, of January 14, 2004 (BRASIL, 2004), being classified as a complexing agent in fertilizer formulations for foliar and fertigation application. The Ascophyllum nodosum stands out among the marine species commonly used in agricultural production. This alga has been extensively studied for its properties, which allow greater development of plants (KHAN et al., 2009; GUPTA; ABU-GHANNAM, 2011).

The biostimulants derived from the seaweed extract Ascophyllum nodosum are constituted by several phytohormones, mainly auxins and cytokinins, presenting different concentrations (DURAND et al., 2003; RAYIRATH et al., 2008), as well as betaines (MACKINNON et al., 2010), organic and inorganic compounds, essential nutrients, carbohydrates and amino acids (RIOUX et al., 2007). Furthermore, gibberellins, abscisic acid, jasmonic acid, polyamines and alginates were already described (TARAKHOVSKAY et al., 2007; KHAN et al., 2009).

In this context, this study aimed to verify the effects of different doses of $A$. nodosum and thidiazuron on the fruit set and yield of 'Gala' apple trees.

\section{Materials and methods}

The experiment was carried out in Porto Amazonas, State of Paraná, Brazilian Southern, during two cycles (2015/2016 and 2016/2017), in a commercial orchard with geographic coordinates of $25^{\circ} 29^{\prime} 25.4^{\prime \prime} \mathrm{S}$ and $49^{\circ} 54^{\prime} 44.1$ " $\mathrm{W}$ and $938 \mathrm{~m}$ of altitude. The apple trees cv. Gala were 15 years old, grafted on 'Marubakaido' rootstock with EM-9 intergraft, conducted in a central leader system and spaced $4 \times 1 \mathrm{~m}$. Pollinating plants of the genus Malus sp. were intercropped in the orchard in a ratio of 1:6.

The following commercial products were used for the treatments: Dropp ${ }^{\circledR}\left(120 \mathrm{~g} \mathrm{~L}^{-1}\right.$ thidiazuron, Bayer), Algamare ${ }^{\circledR}\left(290 \mathrm{~mL} \mathrm{~L}^{-1}\right.$ Ascophyllum nodosum extract, Microquímica). The experimental design was in randomized complete blocks with eight treatments, five replicates and one-whole-plant plot. The treatments were as follows: 1) control (without treatment), 2) TDZ $10 \mathrm{mg} \mathrm{L}^{-1}$, 3) TDZ $15 \mathrm{mg} \mathrm{L}^{-1}$, 4) Algamare $^{\circledR} 0.1 \%$, 5) Algamare $^{\circledR} 0.2 \%, 6$ ) Algamare $^{\circledR} 0.3 \%, 7$ ) Algamare $^{\circledR} 0.4 \%$, 8) Algamare $^{\circledR} 0.6 \%$.

Treatments consisted of spraying the different products in a single application at the F2 phenological stage, which corresponds to full bloom, with $70 \%$ of open flowers (FLECKINGER, 1953). In the first cycle, spraying occurred on 09/09/2015 and in the second cycle on $09 / 19 / 2016$. The treatments were applied with a motorized costal spray, using a volume equivalent to 
1,000 $\mathrm{L} \mathrm{ha}^{-1}$, aiming to achieve the complete wetting of the whole plant. Fruit thinning was performed leaving one apple per inflorescence, 40 days after full bloom. The harvest was carried out on 01/25/2016, and 01/18/2017, for the first and second cycle, respectively.

For the two consecutive cycles, the following variables were evaluated:

1. Growth of shoots: Five shoots of the year were marked and measured with tape measure, located in the middle third of the plant. This evaluation was performed at the beginning of the experiment and at the fruit harvest date. The averages were compared by growth difference (final growth - initial growth), between the date of application and the date of fruit harvest.

2. Fruit set (\%): relation between the total number of fruits counted between 15 and 30 days after application of the treatments (DAAT) in 100 flowers previously marked. The flower counting was performed at the time of spraying, and the marked flowers were at the phenological stage F2, which corresponds to full bloom. The marked flowers were monitored until the fruits were approximately $20 \mathrm{~mm}$ in diameter and fruit counting were performed at 15 and 30 DAAT, before plant thinning.

3. Number of fruits per plant: counting the total number of fruits per plant and weighing at harvest.

4. Yield (kg): total mass of fruit per plant at harvest, expressed in kilograms.

5. Average fresh fruit weight: obtained by dividing the total mass of fruits harvested per plant by the number of fruits and expressed in grams.

6. Fruit length $(\mathrm{mm})$ : The length of the fruit was measured by measuring the distance between the base (stalk insertion) and the apex, measured with a digital caliper in a sample of 25 fruits per experimental plot.

7. Fruit diameter $(\mathrm{mm})$ : The diameter of the fruits was taken perpendicularly, in the region of larger size of the fruit, with a digital caliper in a sample of 25 fruits per experimental plot.

8. Relationship between length and diameter of fruits $(\mathrm{L} / \mathrm{D})$ : obtained by dividing the length by the diameter.

9. Average number of seeds: evaluated in a sample of 25 fruits per experimental plot

10. Titratable acidity (TA): For this determination, 2 $\mathrm{g}$ of the apples pulp was diluted in $98 \mathrm{ml}$ of distilled water, added with two drops of phenolphthalein (1\% alcohol solution) as indicator. This solution was titrated with $0.1 \mathrm{~N}$ sodium hydroxide solution $(\mathrm{NaOH})(\mathrm{AOAC}, 1984)$, the results being expressed as a percentage of malic acid in $\mathrm{g}$ $100 \mathrm{~mL}^{-1}$ of the sample.

11. Soluble solids (SS): a direct reading was made in a manual refractometer, model RHB-32ATC (AKSO, São Leopoldo - Brazil), with results expressed in percentage.
12. Firmness: determined using a digital penetrometer model DD-200 (Instrutherm, São Paulo - Brazil), with an $8 \mathrm{~mm}$ diameter tip, measurements being taken with the removal of a small portion of the epidermis in the equatorial region of the fruit, and the values expressed in Newton.

The data were submitted to the Analysis of Variance (ANOVA) and the means were compared by the Duncan test $(p \leq 0.05)$, using the Assistat program (SILVA; AZEVEDO, 2016).

\section{Results and discussion}

In general, the fruit set of 'Gala' apple trees were relatively high in both years, in ranges of 60.8 to $65.3 \%$ and 40.2 to $52.2 \%$, respectively. However, the treatments applied had different effects for each year (Figure 1A). In the first cycle (2015/2016), fruit set was approximately $7 \%$ higher for all products applied when compared to the control, without differences between TDZ and Algamare ${ }^{\circledR}$. Nevertheless, in the second cycle, the control treatment showed the highest fruit set (52.2\%), presenting significant difference for the treatment with TDZ $15 \mathrm{mg} \mathrm{L}^{-1}$, which reduced the fruit set by approximately $23 \%$.

The reduction in fruit set in the second cycle could be an evidence of alternate bearing resulted from a regular fruit set in the previous year, and especially higher for the treatments with the TDZ and Algamare ${ }^{\circledR}$ that presented an increase compared to the control. Vieira et al. (2016) verified in apples cv. 'Daiane', fruit set in a range of 9.2$25.2 \%$ for the control plants and from 29.8 to $98.6 \%$ for trees treated with TDZ with doses between 5 and $25 \mathrm{mg}$ $\mathrm{L}^{-1}$. In pears cv. 'Hosui', Pasa et al. (2017) reported an increase of fruit set from $23.0 \%$ in control plants to $70.0 \%$ for treatment with TDZ at $40 \mathrm{mg} \mathrm{L}^{-1}$. Basak (2008) also showed positive effects of application of Ascophyllum nodosum extract product in apple trees, which improved fruiting in some cases.

No significant differences were verified for the number of fruits in the first cycle (2015/2016), although the control plants showed the lowest absolute value (Figure 1B). In the second cycle (2016/2017), the treatment with Algamare $^{\circledR} 0.4 \%$ presented the highest number of fruits per plant, with a significant increase of $30 \%$ compared to control. Moreover, the treatment with Algamare ${ }^{\circledR} 0.4 \%$ did not differ from the other treatments. For the accumulated number of fruits of two consecutive crops, the treatments $\mathrm{TDZ}$ at $10 \mathrm{mg} \mathrm{L}^{-1}$ and Algamare ${ }^{\circledR}$ at 0.2 and $0.4 \%$ were significantly higher than the control, with increases up to $20 \%$. These three treatments did not differ from the other doses applied (Figure 1C). 
Although no effects in fruit set was verified in the second cycle (Figure 1A), the plants treated at full bloom showed higher number of fruits (Figures 1B and 1C). Probably, this could be related to an increase in differentiation of floral primordia in the first cycle of application, allowing a greater number of floral cluster per plant in the second cycle, since the process of differentiation of shoots presents its critical phase during the period of flowering of the previous cycle (BOTELHO et al., 2006; MULLINS et al., 2007; JACKSON, 2008).

Floral induction occurs through biochemical signals that change the state of the tissues from vegetative to reproductive, these signals are regulated by endogenous and exogenous factors (SPANUDAKIS; JACKSON, 2014). Among these factors, the balance of phytohormones such as auxins, gibberellins, cytokinins and ethylene (WESTWOOD, 1993) stand out. Other hormones, including abscisic acid (ABA), jasmonate (JA), salicylic acid (SA), brassinosteroids (BRs) and nitric oxide also play a role in the regulation of flowering (KAZAN; LYONS, 2016).

Flowering is a process under hormonal control, and external factors exert influence in this process by the biochemical modification of the plant, particularly in the hormonal balance. At an initial stage, the gibberellins promote flowering because they induce the formation of the undifferentiated primordia. Afterwards, gibberellins act as inhibitors of flowering, since they direct the undifferentiated primordia to the formation of vegetative shoots (BOTELHO et al., 2006; MULLINS et al., 2007; CRANE et al., 2012). On the other hand, cytokinins are necessary for the differentiation of the undifferentiated tissue into inflorescence primordial (CRANE et al., 2012).

Shikhamany (1999), when studying the effect of the application of plant regulators on vines cvs. 'Cabernet Sauvignon' and 'Muscat of Hamburg', found that in order to obtain satisfactory bud fertility it is a necessary to have an adequate ratio of endogenous cytokinins/gibberellins during the different stages. Mullins et al. (2007) reported on the importance of this hormonal balance in the induction and formation of the floral buds and reported the activity of the chlormequat on the inhibition of gibberellin synthesis and increase cytokinins production, causing the plants to flower.

Contrasting with our results, Amarante et al. (2002) reported 50\% decreases in return bloom in 'Gala' apples treated in the previous year with TDZ at 10 or $20 \mathrm{mg}$ $\mathrm{L}^{-1}$, but not in cv. 'Fuji'. According to these authors, the reduced return bloom in 'Gala' treated with the highest doses of TDZ may be the result of previous higher fruit set, which can cause depletion of reserves for the flower bud differentiation (FAUST, 1989), and/or promotion of vegetative shoot growth, that can also affect flower bud differentiation (TAIZ; ZEIGER, 2004). Amarante et al. (2002) verified a two-fold increase in fruit set for the 'Gala' apple trees treated with TDZ at $20 \mathrm{mg} \mathrm{L}^{-1}$, much higher than our finds (around 7\%). In the application of product composed of Ascophyllum nodosum extract there was improvement in the quality of the flowers and prolongation of the period of flowering confirming positive effect in the floral organs (BASAK, 2008).

For the evaluations of fruit weight in the first cycle, the treatment Algamare ${ }^{\circledR} 0.1 \%$ was significantly superior to the treatments control, TDZ $10 \mathrm{mg} \mathrm{L}^{-1}$ and Algamare $^{\circledR} 0.6 \%$, but did not differ from the other treatments (Figure 2A). In the second cycle, there were no significant differences for this evaluation. According to Wertheim and Webster (2005), the application of synthetic cytokinins such as TDZ stimulates cell division and elongation, promoting fruit growth. The extracts based on Ascophyllym nodosum algae contain several compounds which could action on the development of the fruits, such cytokinins, auxins, abscisic acid, gibberellins, betaines and alginates (STIRK et al., 2004; TARAKHOVSKAY et al., 2007; MACKINNON et al., 2010; SHARMA et al., 2012; CHOJNACKA et al., 2012).

For the results of yield per plant in the first cycle, treatment with Algamare ${ }^{\circledR} 0.3 \%$ presented the highest average, being significantly superior to the treatments with Algamare $^{\circledR} 0.6 \%$ and TDZ in the doses of 10 and $15 \mathrm{mg}$ $\mathrm{L}^{-1}$. In the second cycle, the majority of the treatments with applications at full bloom were significantly superior to the control. The highest yield was verified for TDZ treatment at $15 \mathrm{mg} \mathrm{L}^{-1}\left(27.0 \mathrm{~kg} \mathrm{plant}^{-1}\right)$, followed by the applications of Algamare ${ }^{\circledR} 0.3 \%$ (25.7 kg plant $\left.^{-1}\right)$ and Algamare ${ }^{\circledR} 0.1 \%$ $\left(25.2 \mathrm{~kg} \mathrm{plant}^{-1}\right)$ and TDZ $10 \mathrm{mg} \mathrm{L}^{-1}\left(25.1 \mathrm{~kg} \mathrm{plant}^{-1}\right)$ that were significantly superior to the control plants $(21.4 \mathrm{~kg}$ plant $^{-1}$ ) (Figure 2B). The increase in yield was up to $25 \%$ compared to the control, corroborating with the results obtained by Villardell et al. (2008), who verified that applications of plant regulators in pear trees cv. 'Abate Fetel' at full bloom, increased fruit yield in $40 \%$. The increase in productivity observed in the second cycle of the experiment was mainly due to the increase in number of fruits per plant (Figure 1B). Considering the accumulated yield in two cycles, the treatment with Algamare ${ }^{\circledR} 0.3 \%$ increased significantly the production in $12.5 \%$ in relation to control, but did not differ from the other treatments.

Vieira et al. (2016) found in the second cycle of their experiment a significant increase in fruit production of plants treated with TDZ compared to the untreated plants, especially the plants treated with the concentration of $10 \mathrm{ppm}$ TDZ, which expressed production per plant (kg) $188.2 \%$ higher than untreated plants. On average, treatments with TDZ applications showed an additive effect on production variables. In studies with tomatoes fruit production was measured in the two field experiments and the plants treated with Ascophyllum nodosum extract had significantly higher yields compared to controls in both experiments (ALI et al., 2015). Norrie et al. (2006) 
also verified the effects of Ascophyllum nodosum extract on the quality and production of 'Thompson seedless' grapes during 3 years of experiment, it was observed by the authors that the extract provided a significant increase in total production and quality.

Differences in fruit diameter were verified only in the first cycle. The treatment with Algamare ${ }^{\circledR}$ at $0.1 \%$ provided wider fruits compared to treatments with TDZ at 10 and $15 \mathrm{mg} \mathrm{L}^{-1}$, and Algamare ${ }^{\circledR}$ at 0.3 and $0.6 \%$ (Figure 3A). For the measurements of fruit length (mm), no significant differences were observed in the first cycle. However, in the second cycle, all treatments differed significantly from the control, promoting the production of longer fruits (Figure 3B). No significant differences were observed for $\mathrm{L} / \mathrm{D}$ ratio in any of the evaluated cycles (data no shown). However, Petri et al. (2001) observed that TDZ caused deformations in apple fruits, affecting the direction of cell division and expansion. In an experiment developed with kiwifruit (Actinidia deliciosa) the leaf application of an extract of algae of Ascophyllum nodosum increased the size of the fruits (CHOULIARAS et al., 2009).

No significant differences were verified for the growth of shoots in the first cycle (Figure 3C). However, in the second cycle, the treatment Algamare ${ }^{\circledR} 0.4 \%$ induced the highest shoot growth when compared to the control and treatments with TDZ 10 and $15 \mathrm{mg} \mathrm{L}^{-1}$ and Algamare ${ }^{\mathbb{B}}$ 0.1 and $0.3 \%$. Mancuso et al. (2006) observed that $A$. nodosum extract was efficient in promoting vegetative growth of vines and similar effects were observed in watermelon and apple trees (BASAK, 2008; ABDELMAWGOUD et al., 2010). Moreover, treatments with TDZ $10 \mathrm{mg} \mathrm{L}^{-1}$ and Algamare ${ }^{\circledR}$ 0.3\% presented lower growth of the shoots compared to the control (Figure 3C). These results may be related to the higher productivity obtained in these treatments (Figure 2B), and, therefore, the greater competition for photo-assimilates between fruits and growing shoots. Koyama et al. (2012) found that $A$. nodosum extract stimulated vegetative growth in the early stages and promoted reproductive growth in the more advanced stages of crop development.

No significant differences between treatments was verified for the soluble solids content in the first cycle (Figure 4A), corroborating with the results of the studies reported by Botelho et al. (2003), who observed that the applications of gibberellic acid and TDZ in 'Niagara Rosada' grapes did not present significant effect on total soluble solids and titratable acidity.

However, in the second cycle, control fruits had the highest soluble solids content, differing significantly from the treatments with TDZ $15 \mathrm{mg} \mathrm{L}^{-1}$ and Algamare ${ }^{\circledR}$ $0.3 \%$ (Figure $4 \mathrm{~A}$ ). Observing the results of number of fruits (Figure 1B), it can be inferred that higher fruit load determine the reduction of soluble solids contents in the fruits, corroborating with the results obtained by Hawerroth et al. (2011) with mixtures of PCa and TDZ.
There were no differences between the treatments for the results of titratable acidity (4B) and pulp firmness (data not shown), indicating that the products applied in full bloom did not interfere in the ripening of the fruits.

In the first cycle, the treatment with Algamare ${ }^{\circledR}$ $0.6 \%$ presented the lowest number of seeds per fruit, leading to a reduction of $20 \%$ in relation to control (Figure 4C), owever, without differences to the other treatments. In the second cycle, there was no statistical difference between treatments, with an average of 2.5 seeds per fruit. Pasa et al. (2017) reported that seed number was reduced linearly as increasing TDZ rate in 'Hosui', while no significant effects were observed in 'Packham's Triumph'. Reduction in seed number might be expected in response to TDZ, since this substance tends to increase the rate of parthenocarpic fruits, as observed in 'Packham's Triumph' pears (PETRI et al., 2001). 

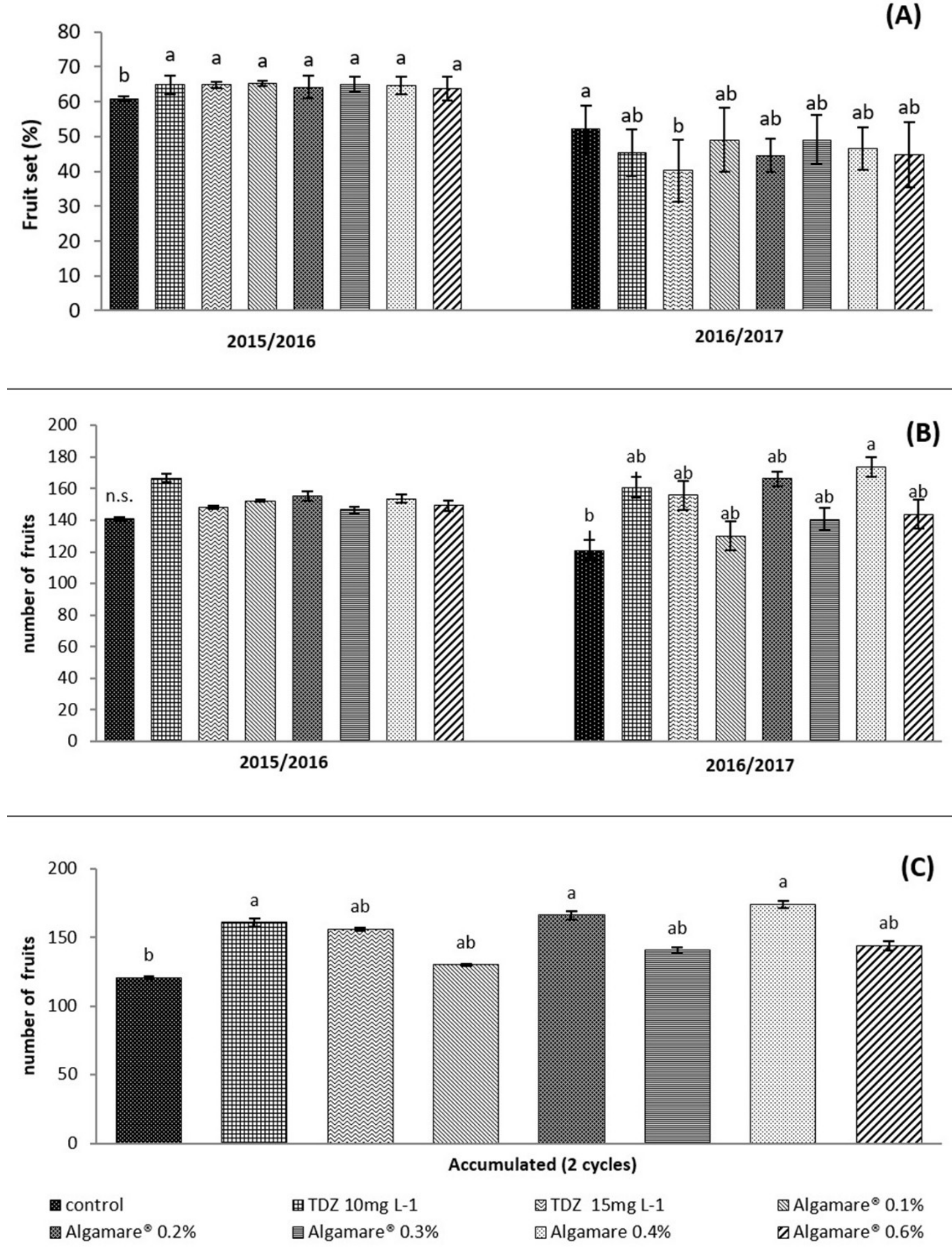

Figure 1. Fruit set (A), number of fruits per cycle (B) and accumulated (C) of apple trees cv. 'Gala' treated with different products at full boom (B) (Porto Amazonas-PR, Brazil, 2018). Means followed by the same letter did not differ by Duncan test $(\mathrm{p} \leq 0.05)$. Vertical bars represent standard deviation $(\mathrm{n}=5) . \mathrm{ns}=$ not significant. 

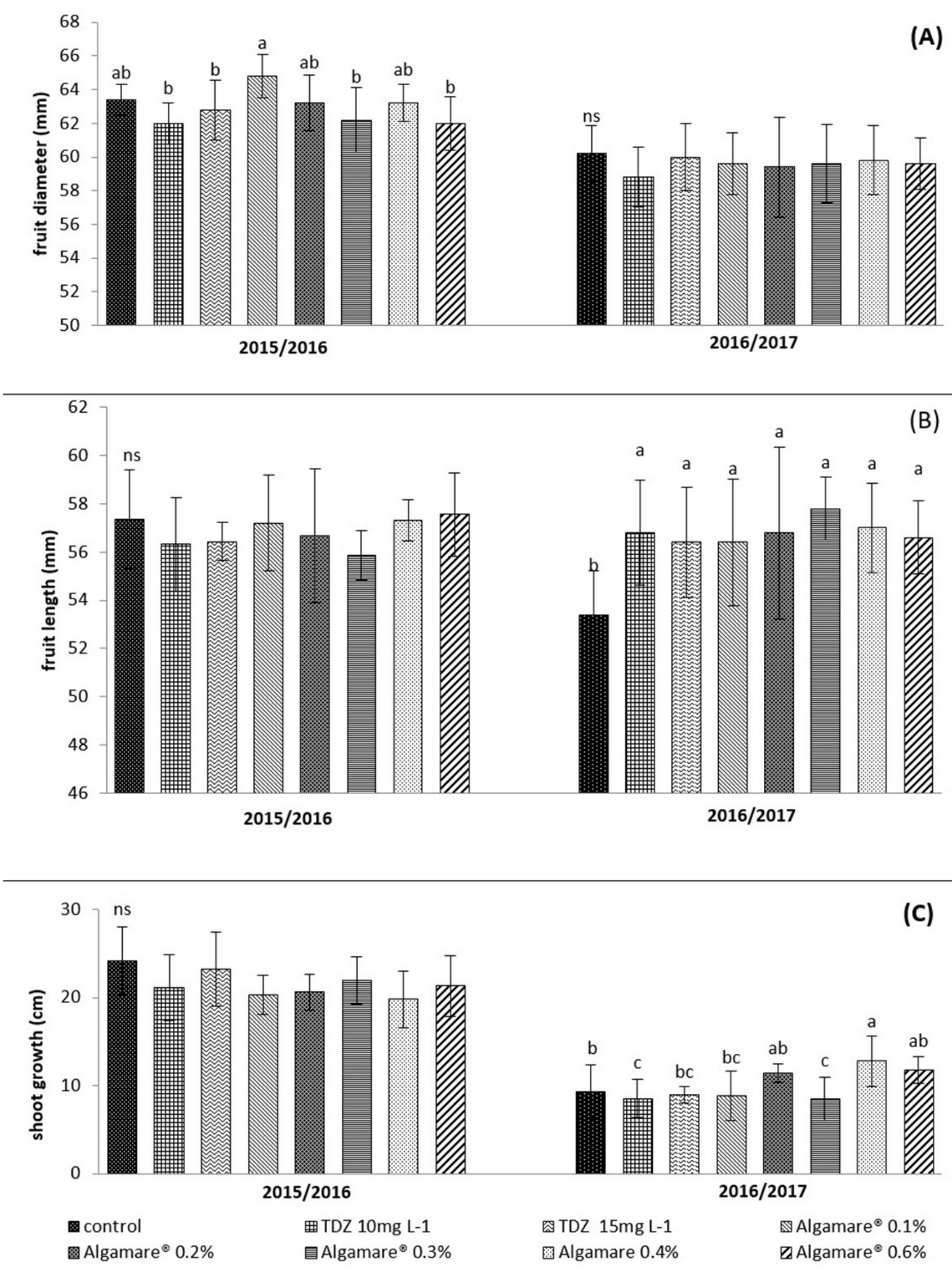

Figure 2. Fruit weight (A), yield per crop (B) and accumulated yield (C) of apples trees cv. 'Gala' treated with different products at full bloom (B) (Porto Amazonas-PR, Brazil, 2018). Means followed by the same letter did not differ by Duncan test $(p \leq 0.05)$. Vertical bars represent standard deviation $(n=5)$. 

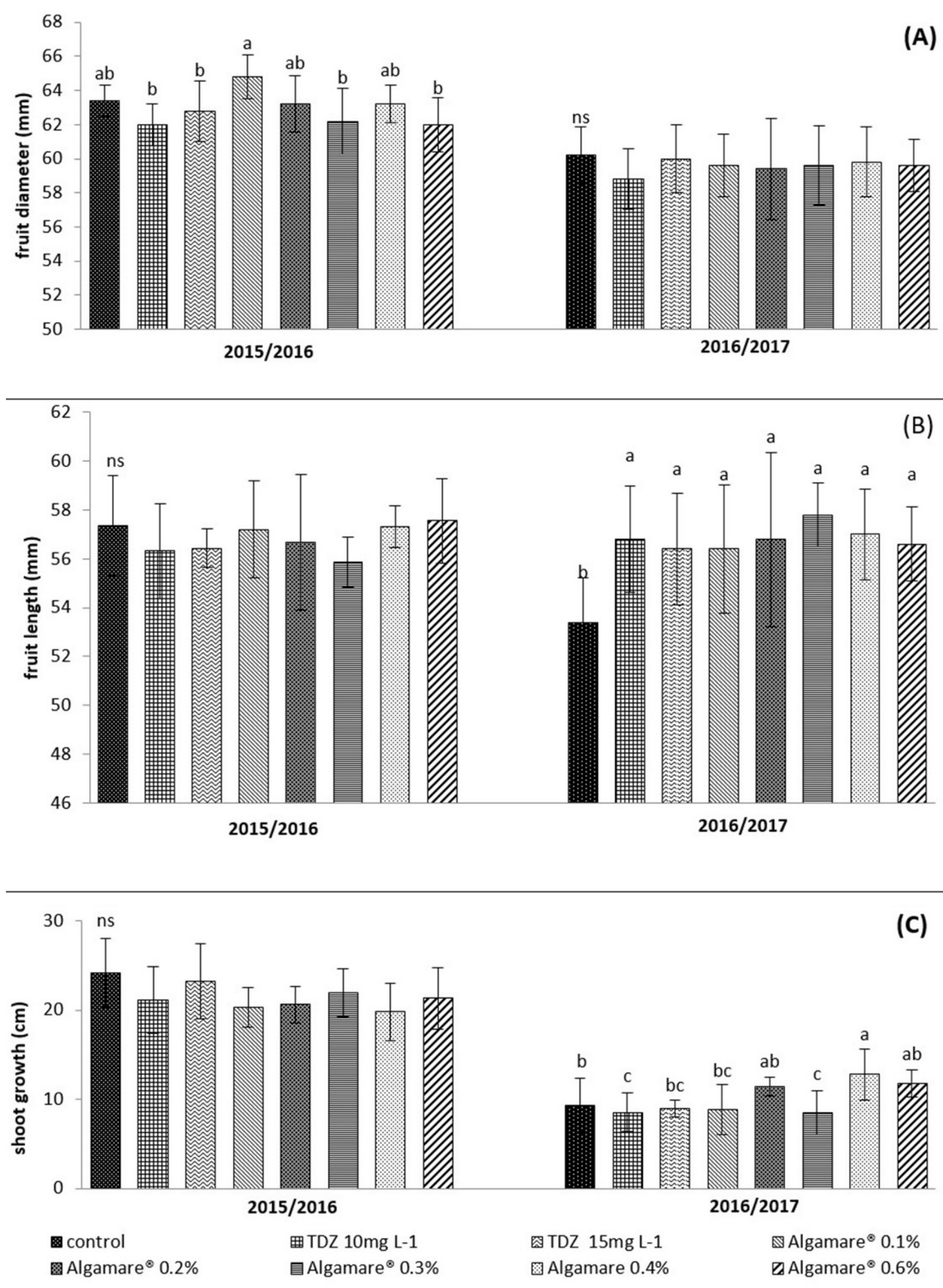

Figure 3. Diameter (A) and length of fruits (B) and; shoot growth (C) of apples cv. 'Gala' from plants treated with different products at full bloom (B) (Porto Amazonas-PR, Brazil, 2018). Means followed by the same letter did not differ by Duncan test $(p \leq 0.05)$. Vertical bars represent standard deviation $(\mathrm{n}=5)$. $\mathrm{ns}=$ not significant. 

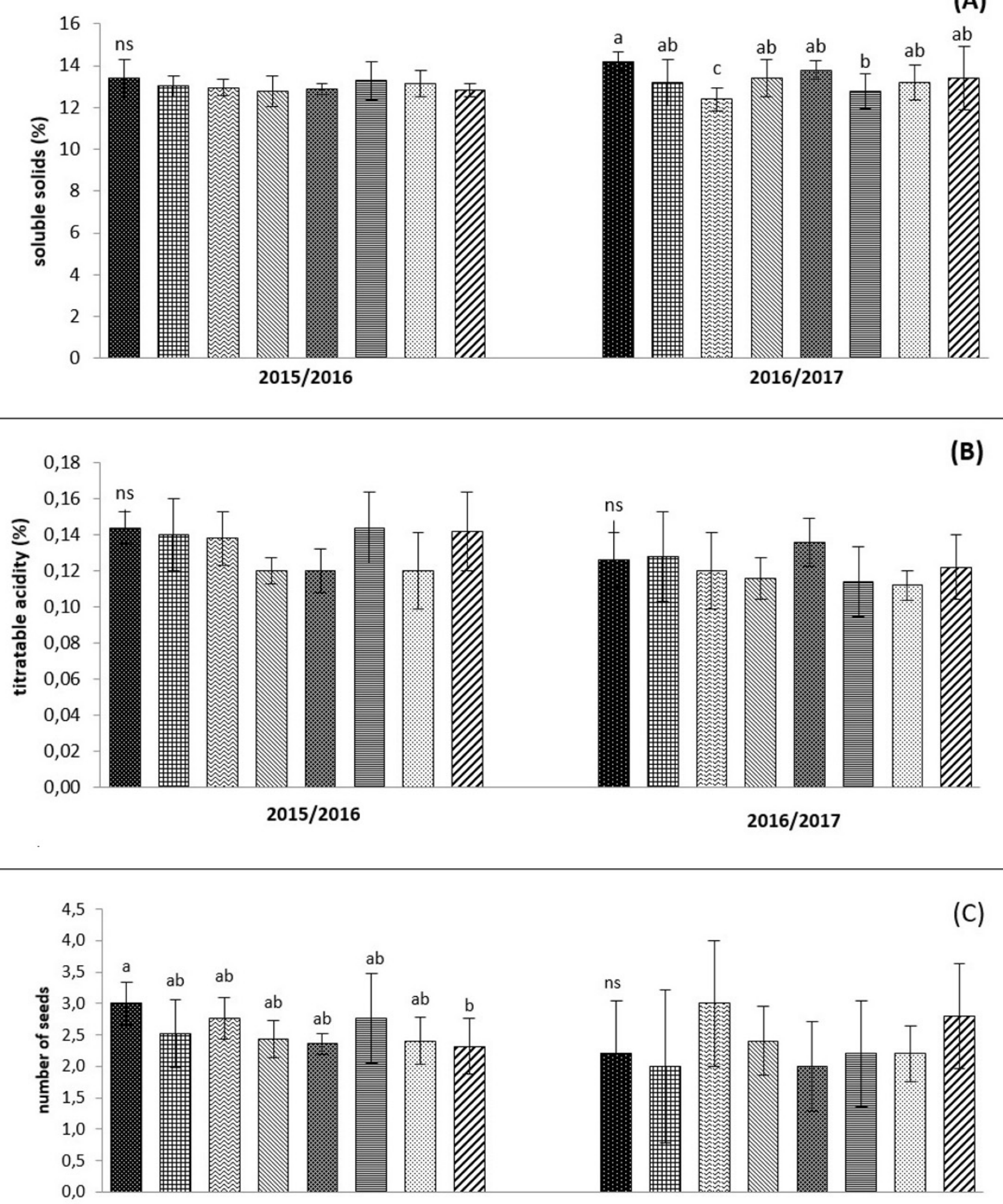

2015/2016

\begin{tabular}{|c|c|}
\hline control & 田 TDZ (Drop ${ }^{\ominus}$ ) 10mg/L \\
\hline 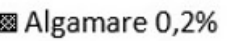 & 目Algamare $0,3 \%$ \\
\hline
\end{tabular}

2016/2017

$\mathbb{Q}$ Algamare $0,1 \%$

\Algamare $0,6 \%$

Figure 4. Soluble solids (A), titratable acidity (B) and number of seeds (C) of apples cv. 'Gala' from plants treated with different products at full bloom (B) (Porto Amazonas-PR, Brazil, 2018). Means followed by the same letter did not differ by Duncan test $(\mathrm{p} \leq 0.05)$. Vertical bars represent standard deviation $(\mathrm{n}=5)$. $\mathrm{ns}=$ not significant. 


\section{Conclusions}

According to our results, the algae extract of $A$. nodosum presented similar effects of thidiazuron in apple trees, promoting, in at least one of the cycles, the increase in fruit set, number of fruits, weight and length of fruits without change their maturation. Because it is a natural product and is effective in low concentrations, it has great potential for use in more sustainable production systems and can be considered an alternative technology to organic management. The application of Algamare ${ }^{\circledR}$ at $0.3 \%$ was the most effective treatment for yield improvement in 'Gala' apples.

\section{References}

ABDEL-MAWGOUD, A.M.R.; TANTAWAY, A.S.; HAFEZ, M.; HABIB, H.A.M. Seaweed extract improves growth, yield and quality of different watermelon hybrids. Research Journal of Agriculture and Biological Sciences, Faisalabad, v.6, p.161-168, 2010.

ABPM - Associação Brasileira de Produtores de Maçã. Anuário brasileiro da maçã 2016. 2. ed. Santa Cruz do Sul: Editora Gazeta Santa Cruz, 2017. 64 p.

ALI，N.; FARRELL，A.; RAMSUBHAG，A.; JAYARAMAN, J. The effect of Ascophyllum nodosum extract on the growth, yield and fruit quality of tomato grown under tropical conditions. Journal of Applied Phycology, Doredrecht, v.28, p.1353-1362, 2016.

AMARANTE, C.V.T.; SIMIONI, A.; MEGGER, C.; BLUM, L.E. Effect of aminoethoxyvinilglycine (AVG) on preharvest fruit drop and maturity of apples. Revista Brasileira de Fruticultura, Jaboticabal, v.24, n.3, p.661664, 2002.

AOAC - Association of Official Analytical Chemists. Official methods of analysis. 14. ed. Washington, 1984. $937 \mathrm{p}$.

BASAK, A. Effect of preharvest treatment with seaweed products, Kelpak ${ }^{\circledR}$ and Goëmar BM 86 , on fruit quality in apple. International Journal of Fruit Science, Binghamton, v.8, p.114, 2008.

BOTELHO, R.V.; PIRES, E.J.; TERRA, M.M. Bud fertility in vines: physiology and factors involved. Revista Ambiência Guarapuava, Guarapuava, v.2, n.1, p.129144, 2006.
BOTELHO, R.V.; PIRES, E.J.; TERRA, M.M.; CARVALHO, C.R. Efeitos do thidiazuron e do ácido giberélico nas características dos cachos e bagas de uvas 'Niagara rosada' na região de Jundiaí-SP. Revista Brasileira Fruticultura, Jaboticabal, v.25, n.1, p.96-99, 2003.

BRASIL. Decreto n ${ }^{\circ} .4 .954$, de 14 de Janeiro de 2004. Diário Oficial da União, Poder Executivo, Brasília, DF, 15 jan. 2004. Seção 1, p.2. Disponível em: $\leq$ http://extranet. agricultura.gov.br/sislegis-consulta/consultarLegislacao. do; $>$. Acesso em: 21 maio 2018.

CAMILO, A.P.; DENARDI, F. Cultivares: descrição e comportamento no sul do Brasil. In: EPAGRI. A cultura da macieira. Florianópolis, 2006. p.113-168.

CARVALHO, M.E.A.; CASTRO, P.R.C.; GALLO, L.A.; FERRAZ JUNIOR, M.V.C. Seaweed extract provides development and production of wheat. Agrarian, Dourados, v.7, p.166-170, 2014.

CARVALHO, M.E.A.; CASTRO, P.R.C.; NOVEMBRE, A.D.L.C.; CHAMMA, H.M.C.P. Seaweed extract improves the vigor and provides the rapid emergence of dry bean seeds. American Eurasian Journal of Agricultural and Environmental Science, Dubai, v.13, p.1104-1107, 2013.

CHOJNACKA, K.; SAEID, A.; WITKOWSKA, Z.; TUHY, L. Biologically active compounds in seaweed extracts-the prospects for the application. The Open Conference Proceedings Journal, Beijing, v.3, p.20-28, 2012.

CHOULIARAS V.; TASIOULA, M.; CHATZISSAVVIDIS, C.; THERIOS, I. TSABOLATIDOU, E. The effects of a seaweed extract in addition to nitrogen and boron fertilization on productivity, fruit maturation, leaf nutritional status and oil quality of the olive (Olea europaea L.) cultivar Koroneiki. Journal of the Science Food and Agriculture, New York, v.89, p.984-988, 2009.

CRAIGIE, J.S. Seaweed extract stimuli in plant science and agriculture. Journal of Applied Phycology, Dordrecht, v.23, p.371-393, 2011.

CRANE, O.; HALALY, T.; PANG, X.; LAVEE, S.; PERL, A.; VANKOVA, R.; OR, E. Cytokinin-induced VvTFL1A expression may be involved in the control of grapevine fruitfulness. Planta, Berlin, v.235, p. 181-192, 2012. 
DURAND, N.; BRIANT, X.; MEYER, C. The effect of marine bioactive substances (NPRO) and exogenous cytokinins on nitrate reductase activity in Arabidopsis thaliana. Physiologia Plantarum, Malden, v.119, p.489493, 2003.

FAOSTAT - Food and Agriculture Organization of the United Nations. Statistical databases. 2014. Disponível em: $\leq$ http://www.fao.org/statistics/en/> . Acesso em: 16 jul. 2015.

FAUST, M. Physiology of temperate zone fruit trees. New York: J. Wiley, 1989. 338 p.

FLECKINGER, J. Observations récents sur l'écologie du pommier à cidre. In: CONGRÈS INTERNATIONAL DE BOTANIQUE ET D“AGRONOMIE, 1953, Versailles. Comunication 8... Versailles: INRA, Station d'Amélioration des Plantes, 1953. p.14.

FLETCHER, R.A. R.; GILLEY, A.; SANKHLA, N.; DAVIS, T.D. Triazoles as plant growth regulators and stress protectants. Horticultural Reviews, New York, v.24, p.55-138, 2000.

GUPTA, S.; ABU-GHANNAM, N. Recent developments in the application of seaweeds or seaweed extracts as a means for enhancing the safety and quality attributes of foods. Innovative Food Science and Emerging Technologies, Amsterdam, v.12, n.4, p.600-609, 2011.

HAWERROTH, F.J.; HERTER, F.G.; FACHINELLO, J.C.; PETRI, J.L.; PREZOTTO, M.E.; HAAS, L.B.; PRETTO, A. Aumento da produção de pereira asiática pelo uso de fitorreguladores. Ciência Rural, Santa Maria, v.41, n.10, p.1750-1754, 2011.

JACKSON, R. S. Grapevine structure and function In: JACKSON, R.S. (Ed.). Wine science principles and applications. 3.ed. San Diego: Academic Press, 2008. p.50-107.

KAZAN, K.; LYONS, R. The link between flowering time and stress tolerance. Journal of Experimental Botany, Oxford, v.67, p.47-60, 2016.

KHAN, W.; RAYIRATH, U.P.; SUBRAMANIAN, S.; JITHESH, M.N.; RAYIRATH, P.; HODGES, D.M.; CRITCHLEY, A.T; CRAIGIE, J.S.; NORRIE, J.; PRITHIVIRAJ, B. Seaweed extracts as biostimulants of plant growth and development. Journal of Plantgrowth Regulation, Secaucus, v.28, p.386-399, 2009.
KOYAMA, R.; BETTONI, M.M.; RODER, C.; DE ASSIS, A.M.; ROBERTO, S.R.; MOGOR, A.F. Seaweed extract of Ascophyllum nodosum (L.) on tomato yield and vegetable development. Amazon Journal of Agricultural Environmental Science, Belém, v.55, p.282-287, 2012.

MACKINNON, S.A.; CRAFT, C.A.; HILTZ, D.; UGARTE, R. Improved methods of analysis for betaines in Ascophyllum nodosum and its commercial seaweed extracts. Journal of Applied Phycology, Dordrecht, v.22, p.489-494, 2010.

MANCUSO, S.; AZZARELlO, E.; MUGNAI, S.; BRIAND, X. Marine bioactive substances (IPA extract) improve foliar íon uptake and water stress tolerance in potted Vitis vinifera plants. Advances in Horticultural Science, Firenze, v.20, p.156-161, 2006.

MULLINS, M. G.; BOUQUET, A.; WILLIAMS, L. E. Biology of the grapevine. Cambridge: University Press, 2007. $239 \mathrm{p}$.

NORRIE, J.; HILTZ, D.A. Agricultural applications using Ascophyllum seaweed products. Agro Food Industry Hi Tech, Milan, v.2, p.15-18, 1999.

NORRIE, J.; KEATHLEY, J. P. Benefits of Ascophyllum nodosum marine-plant extract applications to "Thompson Seedless" grape production. Acta Horticulturae, The Hague, v.727, 2006.

PASA, M.S.; SILVA, C.P.; CARRA, B.; BRIGHENTI, A.F.; SOUZE, A.L.K.; PETRI, J.L. Thidiazuron (TDZ) increases fruit set and yield of 'Hosui' and 'Packham's Triumph' pear trees. Anais da Academia Brasileira de Ciências, São Paulo, v.89, n.4, p.3103-3110, 2017.

PEREIRA, M.C.T.; CRANE, J.H.; NIETSCHE, S.; MONTAS, W.; SANTOS, M.A. Reguladores de crescimento na frutificação efetiva e qualidade de frutos partenocárpicos de atemoia 'Gefner'. Pesquisa Agropecuária Brasileira, Brasília, DF, v.49, n.4, p.281$289,2014$.

PETRI, J. L.; SCHUK, E.; LEITE, G. B. Efeito do thidiazuron (TDZ) na frutificação de fruteiras de clima temperado. Revista Brasileira de Fruticultura, Jaboticabal, v.23, n.3, p.513-517, 2001.

PETRI, J.L.; LEITE, G.B. Macieira. Revista Brasileira de Fruticultura, Jaboticabal, v.30, n.4, p.857-1166, 2008. 
RAYIRATH P.; JITHESH, M.N.; FARID, A.; KHAN, W.; PALANISAMY, R.; HANKINS, S.D.; CRITCHLEY, A.T.; PRITHIVIRAJ, B. Rapid bioassays to evaluate the plant growth promoting activity of Ascophyllum nodosum (L.) Le Jol. using a model plant, Arabidopsis thaliana (L.) Heynh. Journal of Applied Phycology, Dordrecht, v.20, n. 4, p.423-429, 2008.

RIOUX, L .; TUR GEON, S .; B E A U L I EU, M. Characterization of polysaccharides extracted from brown seaweeds. Carbohydrate Polymers, New York, v.69, p.530-537, 2007.

SHARMA, H.S.S.; LYONS, G.; MC ROBERTS, C.; MC CALL, D.; CARMICHAEL, E.; ANDREWS, F.; SWAN, R. Biostimulant activity of brown seaweed species from Strangford Lough: compositional analyses of polysaccharides and bioassay of extracts using mung bean (Vigno mungo L.) and pak choi (Brassica rapa chinensis L.). Journal of Applied Phycology, Dordrecht, v.24, p.1081-1091, 2012.

SHIKHAMANY, S.D. Physiology and cultural practices to produce seedless grapes in tropical environments. In: CONGRESSO BRASILEIRO DE VITICULTURA E ENOLOGIA, 9., 1999, Bento Gonçalves. Anais... Bento Gonçalves: Embrapa-CNPUV, 1999. p.43-48.

SILVA, F.A.S.; AZEVEDO, C.A.V. The Assistat Software Version 7.7 and its use in the analysis of experimental data. African Journal of Agricultural Research, Nairobi, v.11, n.39, p. 3733-3740, 2016.

SPANUDAKIS E.; JACKSON, S. The role of microRNAs in the control of flowering time. Journal of Experimental Botany, Oxford, v.65, p. 365-380, 2014.
STIRK, W.A.; ARTHUR, G.D.; LOURENS, A.F.; NOVÁK, O.; STRNAD, M.; VAN STADEN, J. Changes in cytokinin and auxin concentrations in seaweed concentrates when stored at an elevated temperature. Journal of Applied Phycology, Dordrecht, v. 15, n.31, 2004.

TAIZ, L.; ZEIGER, E. Fisiologia vegetal. 3. ed. Porto Alegre: Artmed, 2004. 719 p.

TARAKHOVSKAY, E.R.; MASLOV, Y.I.; SHISHOVA, M.F. Phytohormones in algae. Russian Journal of Plant Physiology, Moscow, v.54, p.163-170, 2007.

VIEIRA, V.L.S.; PETRI, J.L.; GABARDO, G.C.; ESPERANÇA, A.F.; SEZERINO, A.; SCHVEITZER, B. Efeito de Thidiazuron na frutificação da macieira 'Daiane' em condições adversas a polinização. Revista Eletrônica Científica da UERGS, Porto Alegre, v.2, n.3, p.241-24, 2016.

VILLARDELL, P.; PAGÉS, J.M.; ASÍN, L. Effect of bioregulator applications on the fruit set in 'Abate Fetel' pear trees. Acta Horticulturae, The Hague, v.800, p.169174, 2008.

WERTHEIM, S.J.; WEBSTER, A.D. Rootstocks and interstems. In: TROMP, J.; WEBSTER, A.D.; WERTHEIM, S.J. (Ed.). Fundamentals of temperate zone tree fruit production. Linden: Backhuys Publishers, 2005. p. 400 .

WESTWOOD, M.N. Temperate-zone pomologyphysiology and culture. 3.ed. Portland: Timber Press, 1993. p.523. 